\title{
Acting as Policy Entrepreneurs During COVID-19: The Case of Serbian Think Tanks
}

\author{
Irena Djordjevic* \\ * Department of Social, Political and Territorial Sciences, University of Aveiro, Portugal; \\ irenadjordjevic@rocketmail.com
}

\section{Resumo}

O ponto inicial deste trabalho é a abordagem de fluxos múltiplos de John Kingdon (1984) usada para analisar se os think tanks podem ser reconhecidos como empreendedores políticos durante a crise do COVID-19. Para tal proposta, vai-se examinar o caso dos think tanks sérvios, analisando os problemas que levantaram, as alternativas de política que propuseram e as estratégias que aplicaram. Além disso, ao comparar os problemas trazidos pelos think tanks e a política governamental, avalia-se em que medida as propostas dos think tanks correspondem às que o Governo introduziu. Os resultados mostram que os think tanks selecionados aplicaram diversas estratégias na abordagem dos problemas, que na maioria dos casos foram acompanhadas de propostas específicas sobre como resolvê-los. Além de focar em questões que estão de acordo com sua área de trabalho e fazer referência à sua proposta preferida, também os think tanks levantaram alguns problemas novos, que não estavam na sua agenda antes. Finalmente, mais de metade dos problemas abordados no programa de Governo também foram reconhecidos como importantes pelos think tanks. Portanto, pode-se concluir que os think tanks desempenharam o papel de empreendedores políticos durante a crise do COVID-19, mas para avaliar se foram eles que trouxeram essas ideias aos decisores políticos, é necessária uma análise mais aprofundada.

Palavras-chave: COVID-19; Modelo de Múltiplos Fluxos; Empreendedores políticos; Sérvia; Think tanks 


\begin{abstract}
The starting point of this paper is John Kingdon's (1984) Multiple Streams approach used to analyze whether think tanks can be acknowledged as policy entrepreneurs during COVID-19 crisis. For such purpose, the case of Serbian think tanks is examined, analyzing problems they raised, policy alternatives they proposed along with strategies they applied. Moreover, by comparing issues brought by think tanks and Governmental policy, it is assessed to what extent think tanks proposals match with the ones the Government introduced. The findings show that the selected think tanks applied diverse strategies in addressing problems, which were in majority cases accompanied with specific proposals on how to resolve them. In addition to focusing on issues that are in line with their area of work and referring to their pet proposal, think tanks as well raised some new problems, which were not on their agenda before. Finally, more than half of the problems addressed in the Government program were also recognized as important by think tanks. Therefore, it may be concluded that think tanks played the role of policy entrepreneurs during COVID-19 crisis, but in order to assess whether they were the ones that brought such ideas to policy makers, further analysis is required.
\end{abstract}

Keywords: COVID-19; Multiple Streams Framework; Policy entrepreneurs; Serbia; Think tanks

\title{
1. Introduction
}

Among numerous actors searching for their place on the political stage and competing for the most valuable reward: policy influence, think tanks stand out by their proclaimed independence from other actors and production of policy relevant knowledge through research (Kelstrup, 2016; Rich, 2005; Stone, 1996). Hence, in order to understand how they influence policy making, it is important to answer the following questions: how think tanks delineate one problem as relevant for policy makers, how they develop policy proposals for dealing with such issue, and eventually, which strategies they are applying for making their proposals appealing (Kingdon, 2014). From the viewpoint of policy making, think tanks can influence different stages of this process - in different ways and to different degree (Rich, et al., 2011), but their influence is not always easy to evaluate as the process of transformation of one idea into policy can take decades, with the interaction of numerous agents and modifications of original idea (Weidenbaum, 2010). According to Kingdon's Multiple Streams approach $(1984 ; 2014)$, these agents bringing different ideas into policy market and trying to put them on policy makers' agenda can be considered policy entrepreneurs "willing to invest their resources in return for future policies they favor" (2014, p. 20). This paper assumes think tanks with their unique approach as one of them.

However, COVID-19 pandemic as an unprecedented crisis turning upside down institutions and societies (Bieber, et al., 2020) had an impact even on these policy entrepreneurs as it changed the way the issues are set on the agenda. COVID-19 prompted policy makers to act fast, to create easily implementable policy solutions to 
the challenges imposed to the citizens and economies. Crisis did not force just decision makers to react promptly, but as well think tanks around the world, to come up with constructive and applicable policy contributions, in order to stay relevant and "demonstrate the critical role they play in improving decision-making at a dynamic time" (Gutbrod and Bruckner, 2020, para. 1).

Think tanks' role in policy creation during COVID-19 crisis perhaps is even more important in the contexts with distorted policy processes, such as the case of Serbia, in which "policy making is taking place behind the curtains, public hearings and other means to include stakeholders are rare and often formal...while decision makers see local civil society (and think tanks) as a nuisance that hinder government plans to shape these countries to their liking" (Galushko \& Djordjevic, 2018, p. 207). In such circumstances, think tanks could help to improve the quality of policy making, providing data to assess the importance of the problem and offering diverse policy proposals on how to resolve it (Buldioski, 2009).

On the other hand, a crisis, such as COVID-19, according to Kingdon (2014) can be a trigger for a window of opportunity to open, creating favorable conditions for policy entrepreneurs and their policy proposals to be placed on decision makers' agenda. Thus, here will be examined to what extent proposals advocated by selected Serbian think tanks matched those introduced by the Government. However, it is important to emphasize that the aim is not to measure influence of selected think tanks, as documental analysis is not sufficient for such purpose, but should be the subject of further analysis (Yin, 2003).

Summing-up, this paper analyzes the role of Serbian think tanks as policy entrepreneurs during COVID-19 crisis, taking Kingdon's Multiple Streams approach (1984) as a framework for such analysis. Upon introduction, the following section focuses on elements of the Multiple Streams model important for understanding how policy entrepreneurs influence policy making processes. The third section describes COVID-19 policy response by the Serbian government, in order to assess the extent to which think tanks' proposals match with those adopted by the Government. The fourth highlights the specificities of Serbian think tanks market, while the fifth brings together Kingdon's framework and the findings from document analysis of selected think tanks' policy products. The paper ends with the conclusions of the document analysis, which can serve as the recommendations for other think tanks on how to turn the threat, such as the COVID-19 pandemic, into a window of opportunity for their pet proposals to be to be taken into consideration by policy makers.

\section{Kingdon's Multiple Streams Model}

Since 1984 when John Kingdon published his seminal book Agendas, Alternatives, and Public Policies, the Multiple Streams became one of the most-cited theoretical approaches in this field of policy analysis (see Brunner, 2008; Farley, et al., 2007; Wu, 2018; Zahariadis 1992, 1995). It is a classical agenda setting approach, commonly used for explaining how some issues find their place on the governmental agenda 
(Kingdon, 2014). Kingdon focuses on the initial stage of policy making, and makes differentiation between two processes of particular interest (p. 196). The first one is agenda setting, the process of narrowing from the all possible subjects to those that are worthy for governmental officials to focus on (p. 196). Additionally, unlike other authors who rather use the term 'agenda setting' for both processes, Kingdon introduces the concept of 'alternative specification', and explains that once the problem is placed on the agenda, different policy alternatives are discussed, and some are taken more seriously (p. 4).

In order to answer the questions how "agendas are set and alternatives are specified”, he highlights three processes: problems, policies, and politics (Kingdon, 2014, p. 16). Different policy actors (including think tanks) are recognizing problems, and afterwards are developing policy proposals to tackle such issues and engage in political activities in order to set them on governmental agenda (p. 196).

Regarding problem stream, Kingdon argues that different mechanisms are used by participants to transform regular conditions into important problems, including indicators that show that condition changes; focusing events such as crisis, personal experience or symbols; and formal or informal feedback from existing programs ( $\mathrm{p}$. 197-198). Events in politics such as elections and new administration or changes in national mood have high influence on agenda setting, and contrary to other streams, consensus here is built by bargaining, instead of persuasion (p. 198-199). Problem and politics streams Kingdon is using to explain how the issues are set on agenda, together with the concept of visible participants "those who receive considerable press and public attention", such as president, high government officials, MPs, or political party representatives (p. 199). If they are enhancing the issue, there is high possibility that it will be placed on the agenda (p. 199).

Alternatively, in the policy stream, within the process of alternative specification, hidden cluster participants made of researchers, consultants, academics and bureaucrats are creating plentiful policy solutions for different problems, and pushing for them via public hearings, speeches, media statements, policy products, etc. (p. 200). These policy ideas are floating and blending in "policy primeval soup", making the origin of ideas obscure, but not the selection - it is based on their "technical feasibility, congruence with the values of community members, and the anticipation of future constraints" (p. 200).

Regular or sudden events in either political or problem stream can trigger a window of opportunity to open, followed by coupling of all three streams that creates favorable conditions for the problem to be placed on the agenda or policy alternative to be taken into consideration (p. 201). These policy windows are rare and of short duration, thus "advocates of pet proposals" need to act promptly, keeping their alternatives ready for such opportunity (p. 203-204). Boosting this conjuncture can be brought by policy entrepreneurs, who are ready to invest their resources as an exchange for the policy they are keen on (p. 204). 
Following the approach developed by Kingdon on the US case, empirical studies for Multiple Streams model were conducted for United Kingdom (Münter 2005; Zahariadis, 1995), France (Zahariadis, 1995), Germany (Brunner, 2008; Nill, 2002; Zahariadis, 1995), Canada (Howlett, 1998), Denmark (Bundgaard \& Vrangbæk, 2007), and European Union (Copeland \& James 2014). This paper focuses on Serbian context and the think tanks in the role of policy entrepreneurs, additionally assessing to what extent ideas brought by them correspond with the ones the Government adopted as response to the COVID-19 crisis. In the Figure 1 key elements of Multiple Streams approach along with the hypothesized role of think tanks acting as policy entrepreneurs during COVID-19 is presented.

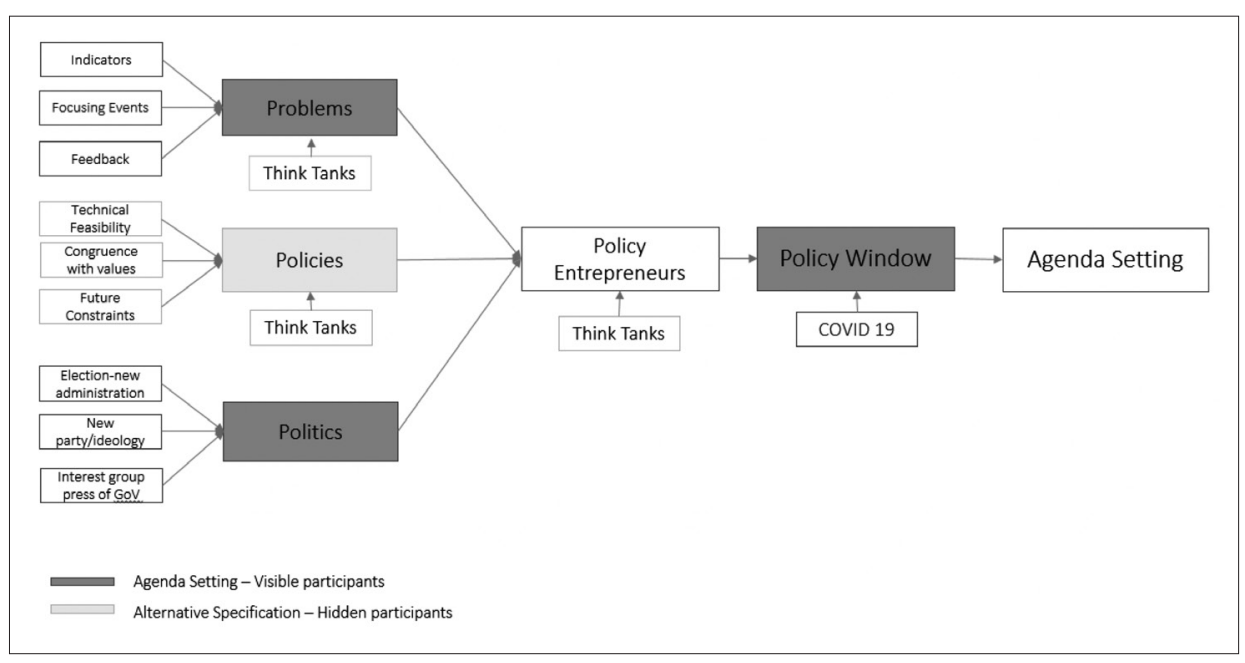

Figure 1. Multiple Streams' Key Elements and the Role of Think Tanks

\section{COVID-19 Policy response}

How does one problem become important for Governments to deal with? Perhaps this question raised by Kingdon (2014) is less relevant when it comes to worldwide pandemic such as COVID-19, "an unprecedented challenge with very severe socio-economic consequence” (European Council, 2020, para. 1). Yet COVID-19 imposed numerous problems that forced decision makers to deal with and respond with urgent policies (OECD, 2020). Soon after health issues, economic problems emerged, competing for their priority on the governments' agendas (United Nations, 2020). In order to mitigate the negative impact of COVID-19 on their economies and secure a sustainable recovery, governments all around the world adopted support packages, consisting of different measures such as "tax and spending, loans and guarantees, monetary instruments, and foreign exchange operations" (IMF, 2020, para. 2). 
So did the Government of Serbia: on April $1^{\text {st }} 2020$ Minister of Finance introduced the EUR 5.1 billion package of measures, equivalent to half of the State budget and $11 \%$ of national GDP, with the aim of stimulating the economy and reducing negative consequences (OECD, 2020). The Adopted Program of Economic Measures is made of four sets of policies, including tax policy measures, direct financial aid to the private sector, liquidity measures and other measures (direct cash grant and moratorium on dividend payments) (The Government of the Republic of Serbia, 2020, p. 10). Meanwhile, during the process of Program creation - as even mentioned in the Program (p. 6) - various policy entrepreneurs were interacting with the Government representatives, addressing important issues (agenda setting) and proposing policy solutions (alternative specification) to be considered when defining a support package. These proposals obtained from the chambers of commerce, university professors, business associations, etc., mostly concerned about the preservation of jobs and the maintenance of liquidity, eventually were taken into consideration, but not all of them were accepted (p. 6). This paper is particularly interested in the role of think tank organizations in creation of COVID-19 package of measures, by analyzing problems they addressed, solutions they offered, strategies they applied, and eventually by assessing to what extent their proposals match with the official Government measures. Before the analysis, a short overview of the think tank market in Serbia is presented.

\section{Serbian think tanks market}

The opinions about think tanks' role in Serbia remain conflicting since the 1990s when they started developing: while optimists considered it as termination of state control over data and research, introduction of evidence-based policy making and credible source for political debate, sceptics claimed that "intellectual elite [is] creating new heavens for their own well-being", that think tanks were donors' project to manipulate new democracies and attempt to make state research capacities even weaker (Buldioski, 2007, p. 51). In addition to the think tanks, similar hybrid organizations that "combine policy research with other functions, such as monitoring and watchdog activities, consulting, service delivery, or grassroots advocacy" (Galushko \& Djordjevic, 2018, p. 208) have as well active role in providing policy advice and research in Serbia, and depending on the authors, these hybrid organizations can be considered think tanks ${ }^{[1]}$ (see Bogdanovic, 2016).

It is a relatively small market: according to McGann (2020) ${ }^{[2]} 14$ think tanks are active in Serbia, mainly covering the topics of European integration, international

1. For instance, Group 484 and European Movement in Serbia are defined as hybrid organizations by Galushko and Djordjevic (2018), while Bogdanovic (2016) defined them as think tanks.

2. Even though McGann ranking provides the most comprehensive list of think tanks all around the world, when it comes to Serbia, according Bogdanovic (2016) it is not reliable. In 2016 Bogdanovic conveyed the mapping starting from McGann list and questioned the figures (for Serbia) as since 2010 this number did not change (it decreased significantly a year later). Bogdanovic claimed this number to be higher as 
relations and social policy, but they deal with cross-sectoral topics too (Bogdanovic, 2016, p. 3). These are rather small organizations with 1 to 3 researchers that due to unstable funding outsource policy consultants and researchers for the needs of specific projects (Bogdanovic, 2016, p. 3). They are often lacking strategic orientation, their credibility is highly dependent on their leaders and are not always transparent in their operations, which contributes to the distrust among decision makers - more on personal base than empirical evidence (Galushko \& Djordjevic, 2018). However, in these three decades of think tanks' presence in Serbia, they were initiators, i.e. policy entrepreneurs for some of the far-reaching policy reforms, including participation of civil society sector in EU accession process and mainstreaming gender equality into security, despite all the obstacles they were facing in such attempts (Bogdanovic, 2016, p. 4).

\section{Results}

Hence, the aim of this paper is to examine whether Serbian think tanks acted as policy entrepreneurs during COVID-19 crisis, and to what extent their policy proposals corresponded with the ones the Government adopted. In order to answer these research questions case study design is applied, examining in detail the activities of four (hybrid) think tanks ${ }^{[3]}$ - European Policy Centre (CEP), National Coalition for Decentralization (NCD), European Movement in Serbia (EMINS) and National Alliance for Local Economic Development (NALED). Even though Galushko and Djordjevic (2018) define NALED and EMINS as hybrid organizations that in addition to policy research perform other, complementary functions, in this analysis following Bogdanovic (2016), a common term think tank will be used for all four organizations.

The following discussion brings together Kingdon's framework and the findings obtained from document analysis, i.e. analysis of policy products of selected cases published on their web sites (54 in total), in the two months period from March $15^{\text {th }}$ to May $15^{\text {th }} 2020$ (see Appendix A), along with the Government Program of Economic Measures adopted in that period to reduce the negative effects of COVID-19.

\footnotetext{
McGann focused only on organizations with research and advocacy capacities, and not on governmental, academic and profit-making think tanks that are active in Serbia, as well as that for years on McGann list there was organization which was no longer active (2016, p. 9). Hence, according to Bogdanovic in 2016 there were 26 active think tanks in Serbia, but not all of them met full criteria ("they research policies, produce their own ideas and communicate/advocate them to policy-making actors") for being defined as such (p. 3).

3. Regarding case selection, activities of two best ranked think tanks from McGann 2019 ranking and two hybrid organizations (Galushko and Djordjevic, 2018) were taken into consideration. Criteria for selection was that they had COVID-19 content on their web sites (C1), and that it was related to the economic measures to mitigate crisis (C2). Three out of eight think tanks from McGann list produced COVID-19 related content $(\mathrm{C} 1)$, and two in the area of economics (C2); while two out of three policy hybrids advocated proposals regarding COVID-19 economic policies (C1 and C2). Therefore, European Policy Centre (CEP) and National Coalition for Decentralization (NKD) are selected as the think tanks' cases, while European Movement in Serbia (EMINS) and National Alliance for Local Economic Development (NALED) are taken as representatives of policy hybrids.
} 
Bearing in mind that "document analysis is often used in combination with other qualitative research methods as a means of triangulation" (Bowen, 2009, p. 28), inference obtained from document analysis here should be treated as the subject of further investigation, and not definite finding (Yin, 2003).

\subsection{Problem Stream}

According to Multiple Stream approach, one of the moments where policy entrepreneurs can be found in the pre-decision process of policy making is in problem stream, by "pushing their concerns about certain problems higher on the agenda" (Kingdon, 2014, p. 204). The findings of the document analysis shows that the activities of Serbian think tanks are in line with Kingdon's conclusion: since the moment the emergency state was declared on March $15^{\text {th }}$ 2020, they started addressing many important issues to be placed on policy makers' agenda -19 in total (see Table 1).

Table 1. List of COVID-19 issues addressed by the selected Serbian think tanks, in the period March 15th - May 15th 2020

\begin{tabular}{|c|c|c|}
\hline No & Issues & Think tanks \\
\hline 1 & Government economic measures to mitigate the negative impact of COVID-19 & $\begin{array}{l}\text { CEP, EMINS, } \\
\text { NALED, NCD }\end{array}$ \\
\hline 2 & $\begin{array}{l}\text { Accountability and Transparency of Parliament and Government during } \\
\text { COVID-19 crisis }\end{array}$ & $\begin{array}{l}\text { EMINS, NCD, } \\
\text { CEP }\end{array}$ \\
\hline 3 & Influence of COVID-19 on modernization of public administration & CEP \\
\hline 4 & Influence of COVID-19 on local governments & NALED \\
\hline 5 & Influence of COVID-19 on labor market & EMINS \\
\hline 6 & Influence of COVID-19 on the youth on labor market & EMINS \\
\hline 7 & Functioning of the health system during COVID-19 crisis & NALED \\
\hline 8 & Influence of COVID-19 on agriculture and beekeeping & NALED \\
\hline 9 & Influence of COVID-19 on construction, infrastructure and transport sectors & NALED \\
\hline 10 & COVID-19 and VAT on food and hygiene products donations & NALED \\
\hline 11 & Illegal actions of economic entities during COVID-19 crisis & NALED \\
\hline 12 & Influence of COVID-19 on travelling & EMINS \\
\hline 13 & Influence of COVID-19 on foreign trade & EMINS \\
\hline 14 & Necessity of regional cooperation to overcome crisis & CEP, EMINS \\
\hline 15 & COVID-19 and EU enlargement (Zagreb Summit) & CEP, EMINS \\
\hline 16 & $\begin{array}{l}\text { Increasing China influence and undermining the credibility of the EU during } \\
\text { COVID-19 crisis }\end{array}$ & CEP \\
\hline 17 & Centralization of information and fake news during COVID-19 crisis & CEP, NCD \\
\hline 18 & Citizens' education about the COVID-19 protective measures & NCD \\
\hline 19 & Role of civil society and think tanks during COVID-19 crisis & CEP, EMINS \\
\hline
\end{tabular}


As one of the criteria for case selection was the presence of the content related to the government economic measures, consequently the problem of negative impact of COVID-19 on the economy was the one discussed by all selected organizations. However, they covered different perspectives: while EMINS focused more on the labor market in general, and the impact on youth in particular, NALED stressed the concerns of the most affected sectors, such as construction, transport and agriculture. CEP and EMINS discussed the importance of regional cooperation and EU paths for Serbia to overcome the crisis, with particularly beneficial roles of civil society and think tanks in such processes (EMINS, CEP). Problems of centralization of information and fake news were under the spotlight of NCD and CEP, while calling for greater accountability and transparency of Parliament and Government (EMINS, CEP, NCD).

Nevertheless, even though these problems might be relevant, not all of them were new, and had already their place on think tanks' agenda before the crisis appeared ${ }^{[4]}$. For instance, the decision of European Policy Centre and European Movement in Serbia (while not NALED and NCD) to discuss the issue of Serbia's European path as a way out of the crisis is in accordance with their organizational orientation towards the EU. Similarly, as membership organization consisted of businesses and local governments, NALED particularly addressed the problems these agents were facing during crisis (reduction of local government revenues, and tax and non-tax burden for businesses); while National Coalition for Decentralization stressed the problem of increasing centralization of governance during crisis, which is in line with what they advocate regardless of COVID-19 crisis.

\subsection{Policy Stream}

In addition to addressing issues to be placed on the governmental agenda, policy entrepreneurs have also an important role in the process of alternative specification and policy stream, by creating and pushing for different policy alternatives (Kingdon, 2014). Similar to this is their role of making couplings, which means they utilize auspicious momentum to link their pet proposals to the pressing problems demanding attention (p. 204). These roles of policy entrepreneurs are as well evident in the case of Serbian think tanks.

The findings show that even though they did not provide policy alternatives for all the problems they addressed, for the vast majority they did: overall, in 24 out of 28 of cases when they raised an issue it was accompanied with the specific recommendation how to deal with it (see Figure 2). Such result is in accordance with the role of a hidden cluster of experts within the policy stream, creating and recreating policy alternatives (Kingdon, 2014, p. 70). However, the complexity and robustness

4. Conclusions in this paragraph are based on the insights obtained from the web sites of selected cases, related to their previous projects and the topics they covered, combined with the results from documental analysis. 
of these proposals vary significantly, from very general and vague to quite much specific and practical solutions. Moreover, here is also evident the difference between selected cases: while NCD provided fewer proposals in general, and more elaborate ones in particular (this also applies to EMINS), CEP and NALED (especially), were way more pragmatic, offering hands-on solutions to the Government and trying to impose themselves as a relevant partners.

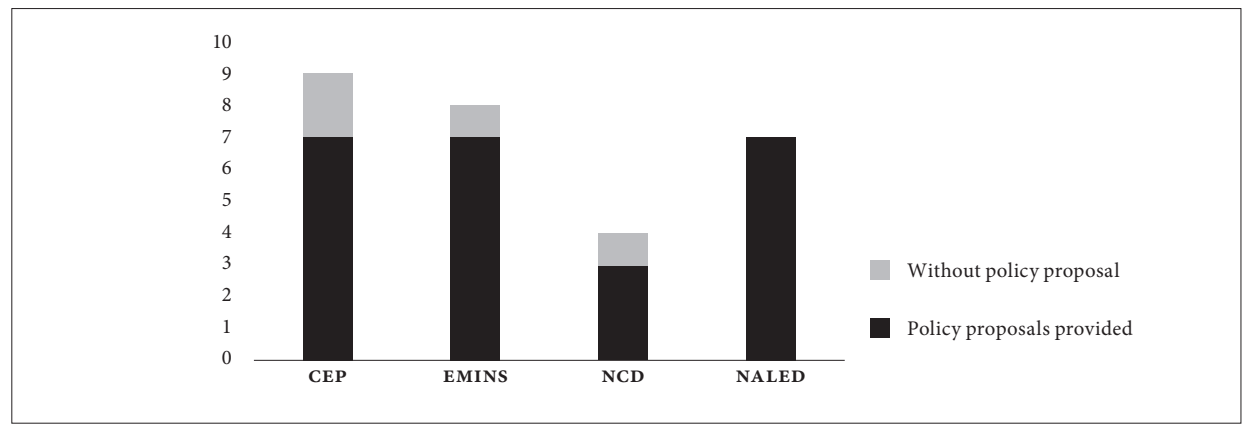

Figure 2. Provision of policy proposals for the issues addressed by the selected think tanks

In the same way they advocated for problems that are in accordance with their area of work, they used the crisis to push for their pet proposals: those think tanks are very keen on, and have already advocated for before the crisis. Each of them took the opportunity to once again promote their preferred solutions: NALED advocated for extension of tax exemption measure for business beginners and implementation of e-Agrar system; NCD called for cooperation between national and local governments to ensure transparency of information; CEP stressed the importance of opening up government data to citizens; while EMINS invited CSOs from the region to make joint forces in order to foster their governments to act coordinated.

\subsection{Pushing forward}

In addition to addressing problems and offering solutions, Kingdon (2014) describes entrepreneurs as those "pushing", which implies specific, accompanying activities of promotion and advocacy. Bearing in mind that the COVID-19 emergency state introduced the banning of gatherings indoors more than five people (Official Gazette of RS, no. 39), and that civil servants have largely switched to working from home, with limited meeting capacity, in this paper, think tanks' web strategies for pushing their proposals were analyzed.

As policy windows are rare and of short duration, policy entrepreneurs need to act promptly, having their pet proposals ready to jump in once the window of oppor- 
tunity opens (Kingdon, 2014). However, among selected think tanks, there was considerable difference regarding the speed of their reaction: while NALED published 10 proposals for the Government to mitigate the crisis a day after emergency state was declared, EMINS published its first COVID-19 content almost a month later (see Appendix A).

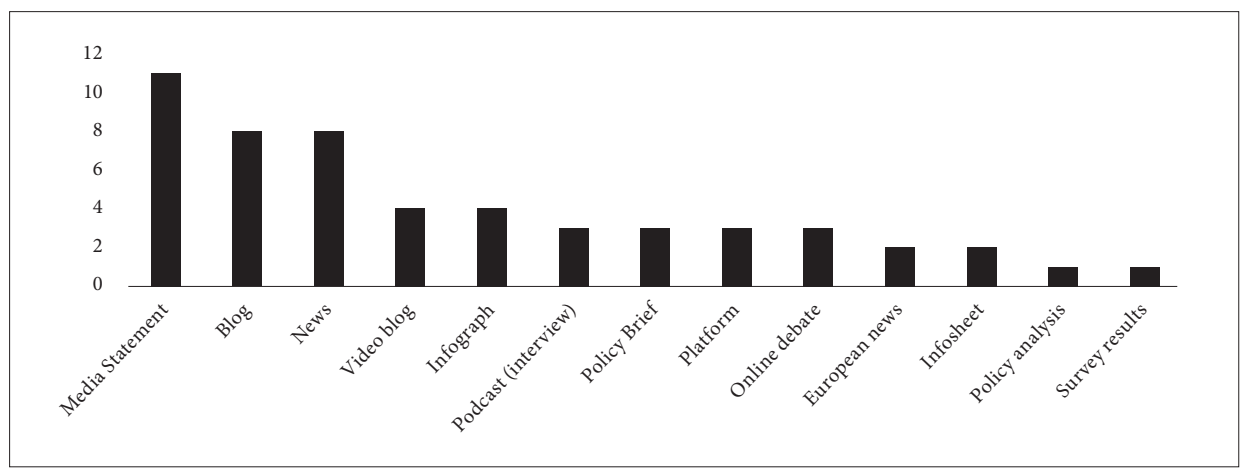

Figure 3. Think tanks' policy products used to push policy proposals on the policy makers' agenda

Regarding the strategies they implemented for "pushing", the most used tool was media statement as a take-away product for media, which facilitates the placement of think tanks' message. NCD and NALED conveyed the online surveys providing original data for their advocacy (in the forms of info-graphs and policy briefs), while self-recorded video content in the form of video blogs (EMINS) and online debates (NCD) were innovative ways to reach the public, without violating the rule of social distancing. Additional strategies applied for strengthening arguments, were putting the same content in different form (for instance, analysis and info-graph, see Appendix A) and acting in coalitions: together with three other organizations ${ }^{[5]}$ NALED pushed for exemptions from VAT on donations; EMINS called for better regional coordination along with 38 organizations; while there was even collaborative activity between selected cases: CEP and NALED organized a joint webinar to discuss adopted economic measures.

With the exception of NALED, think tanks were utilizing experts and their recognizable names to attract attention, in different forms. Half of all content, CEP put in the form of a blog, as an expert opinion, including interpretation of the problem along with recommendations. Similar strategy, but in video format (vlog) EMINS applied, while NCD opted for online debates of internal and external experts. On the other hand, NALED provided much more analytical products compared to others,

5. Charity Coalition, Food Bank and Civic Initiatives. 
based on their original data, and developed sets of practical recommendations for decision makers for different business sectors, Q\&A platform for citizens and donation platform for helping local communities and healthcare institutions.

\subsection{COVID-19: Window of opportunity?}

The last question of this analysis is whether COVID-19 was indeed the policy window for think tanks, i.e. to what extent proposals advocated by policy entrepreneurs matched with those introduced by the Government? In this subsection focus is on the specific policy products made by CEP and NALED ${ }^{[6]}-10$ measures for the Government to introduce to mitigate the negative effects of the crisis. NALED provided even two versions of these proposals: the second edition was modified compared to the first, it was prepared in alliance with other business associations and both were taken as the subject of analysis ${ }^{[7]}$. Even though NALED was officially recognized as one of the relevant contributors in Governmental Program (2020, p. 6), it is important to emphasize that this paper does not aim to measure policy influence of think tanks, as documental analysis is not sufficient for such purpose, but should be the subject of further analysis (Yin, 2003). Instead, it examines the role of think tanks as policy entrepreneurs, and whether and how they benefited from COVID-19 crisis to set their policy proposals on policy makers' agenda.

The findings show that five out of nine measures introduced by the Government were recognized as important by CEP and NALED as well (as seen in Figure 4). While some of their proposals were fully matching, in others cases they had slightly different views on how to resolve these issues (e.g. direct aid for businesses). Reorganization of salary tax and social contributions payments, and provision of loans for businesses' liquidity were proposals advocated by all organizations, while advance payment of corporate income tax was addressed in two (out of three) documents, with different proposals how to deal with it (deferral vs abolishment). NALED also advocated for one-time financial support for businesses, and in coalition with other organizations called for abolishing VAT on donations: both measures corresponding with the Government policy.

6. EMINS published only general recommendations which are not comparable to the one issued by NALED and CEP, while NCD in some of their policy products mentioned Government measures, but did not provide systematic proposals.

7. First set of measures, NALED proposed a day after the emergency state was declared, and 15 days before Program of economic measures was issued, while the second edition was published and submitted to the Government in alliance with Digital Initiative Serbia, AmCham and FIC on March 28th, three days before issuance of the Program. 


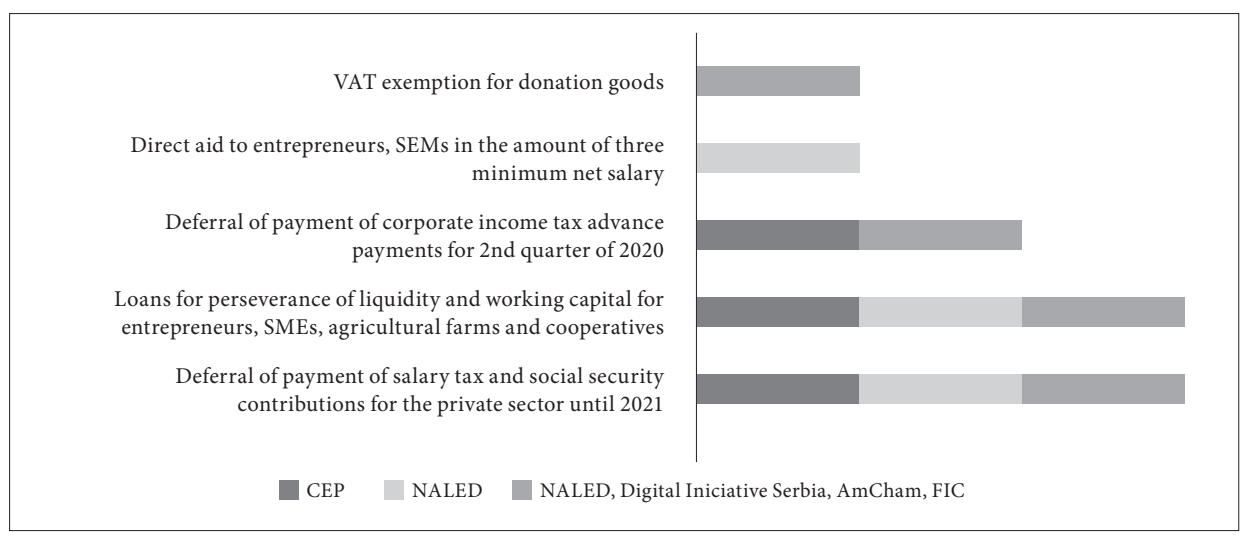

Figure 4. Matching of Government package of economic measures and policy proposals provided by NALED and CEP

Notes: Measures that the Government of Serbia introduced, and were not advocated by selected think tanks are following: Direct aid to large companies in the amount of $50 \%$ of three minimum net salary; Financial support through guarantee scheme to commercial banks; Moratorium on dividend payments; Direct aid to 18+ Serbian citizens through one-off payment.

However, these proposed measures were neither CEP nor NALED pet proposals, but rather responses tailored specifically for this situation ${ }^{[8]}$. For instance, in its annual publication - Grey book (2020, p. 23), NALED advocated for permanent - and not temporary - reduction of the tax burden on wages, while the taxation issues were never on the CEP agenda before the crisis. It means that think tanks were quite flexible to shape their pet proposals in accordance with the new conditions, but also brave enough to deal with the completely new topics in order to stay relevant actors on the policy stage.

\section{Conclusions}

Summing up the findings, it may be concluded that Serbian think tanks played the role of policy entrepreneurs during COVID-19 crisis, acting promptly to seize the window of opportunity and placing the issues with the accompanying pet proposals on policy makers' agenda. Based on the insights obtained from the examined cases in this analysis, the following conclusions, which could serve as recommendations (or know-how) for other policy entrepreneurs, can be made.

First of all, even in the crisis period, think tanks did not recede from their defined strategic orientations: as soon as the emergency state was declared, they started ad-

8. Similarly to the previous subsection, conclusions here are based on the insights obtained from the web sites of selected cases, combined with the results from documental analysis, and with the additional confirmation obtained from conversation with CEP Executive Director. 
dressing the issues they considered important, that were in line with their positions, and were already familiar with. They framed them in the new context of COVID-19 and pushed forward by applying innovative mechanisms for advocacy. However, they did not hesitate to introduce even the new topics on their agenda so as to stay relevant in the changed circumstances.

Additionally, bearing in mind that the creation of policy relevant research is think tanks' uniqueness compared to other policy entrepreneurs, during COVID-19 crisis they acted as the partners offering their know-how to policy makers, i.e. providing specific proposals on how to resolve the relevant problems they addressed. Similarly to their strategy to address the problems already on their agenda, they also tried to utilize the crisis to advocate for their pet proposals. In order to remain important players, some of them developed quite specific, hands-on policy solutions for the Government, eventually conquering their place on the Government's agenda.

COVID-19 demonstrated as well how creative think tanks as policy entrepreneurs can be. In addition to their standard policy products (policy brief, media statement, blog post), in the changed reality they soon found new and innovative ways to disseminate messages to their target audiences, without violating the rule of social distancing, via vlogs, podcasts and online debates. In order to strengthen their arguments they acted in coalitions with other policy entrepreneurs, on both national and regional level, and utilized big names in the field to advocate for their pet proposals.

Finally, even though their approaches for advocacy and promotion differed (considerably in some situations), the proposals Serbian think tanks advocated for matched significantly with those adopted by the Government. However, in order to assess their policy influence, i.e. understand better whether they were the ones bringing such ideas to policy makers, further overarching analysis is needed.

Data de receção: 7/09/2020

Data de aprovação: 24/11/2020

\section{References}

Bieber, F., Prelec, T., Djolai, M., Emini, D., Marović, J., Majstorović, S., ... \& Bartlett, W. (2020). The Western Balkans in Times of the Global Pandemic. Balkans in Europe Policy Advisory Group, 1-37.

Bogdanović, A. (2016). Think tanks in Serbia: in pursuit of impact. In the Research Forum of the European Movement.

Bowen, G. A. (2009). Document analysis as a qualitative research method. Qualitative Research Journal, 9(2), 27-40. doi:10.3316/QRJ0902027

Brunner, S. (2008). Understanding policy change: Multiple streams and emissions trading in Germany. Global Environmental Change, 18(3), 501-507.

Buldioski, G. (2007). Some Musings on Development of Independent Policy Making and Think Tanking in Central and Eastern Europe. Razumkov Centre, National Security and Defence, (6). 
Buldioski, G. (2009). Think Tanks: Untangling the Gordian knot of Policy Research in the Western Balkans. Western Balkans Security Observer-English Edition, (12), 53-67.

Bundgaard, U., \& Vrangbæk, K. (2007). Reform by coincidence? Explaining the policy process of structural reform in Denmark. Scandinavian political studies, 30(4), 491-520.

Copeland, P., \& James, S. (2014). Policy windows, ambiguity and Commission entrepreneurship: explaining the relaunch of the European Union's economic reform agenda. Journal of European Public Policy, 21(1), 1-19.

European Council. (2020). Report on the comprehensive economic policy response to the COVID-19 pandemic. Retrieved from < https://www.consilium.europa.eu/en/press/ press-releases/2020/04/09/report-on-the-comprehensive-economic-policy-response-to-the-covid-19-pandemic/>.

Farley, J., Baker, D., Batker, D., Koliba, C., Matteson, R., Mills, R., \& Pittman, J. (2007). Opening the policy window for ecological economics: Katrina as a focusing event. Ecological Economics, 63(2-3), 344-354.

Galushko, V., \& Djordjevic, M. (2018). Think tanks and 'policy hybrids' in the Western Balkans and post-soviet space. Policy and Society, 37(2), 206-221.

Gutbrod, H. \& Bruckner, T., (2020) Avoiding the asteroid: being constructive and relevant in the pandemic, Retrieved from https://onthinktanks.org/articles/avoiding-the-asteroid-being-constructive-and-relevant-in-the-pandemic

Howlett, M. (1998). Predictable and unpredictable policy windows: institutional and exogenous correlates of Canadian Federal agenda-setting. Canadian Journal of Political Science/Revue Canadienne de Science Politique 31 (3), 495-524

IMF. (2020). Policy Tracker. Retrieved from <https://www.imf.org/en/Topics/imf-and-covid19/Policy-Responses-to-COVID-19>.

Kelstrup, J. D. (2016). The politics of think tanks in Europe. Routledge.

Kingdon, J. W. (2014). Agendas, Alternatives, and Public Policies, Update Edition, with an Epilogue on Health Care' [2 ed.] Pearson.

Kingdon, J. W., \& Stano, E. (1984). Agendas, alternatives, and public policies (Vol. 45, pp. 165 169). Boston: Little, Brown.

McGann, J. G. (2020). 2019 Global Go to Think Tank Index Report. Retrieved from <https:// repository.upenn.edu/cgi/viewcontent.cgi?article=1018\&context=think_tanks $>$.

Münter, M. (2005). Verfassungsreform im Einheitsstaat: Die Politik der Dezentralisierung in Großbritannien. Springer-Verlag.

NALED. (2020). Grey book 12. Retrieved from <https://naled.rs/htdocs/Files/04641/Siva_ knjiga_12.pdf $>$.

Nill, J. (2002). Wann benötigt Umwelt (innovations) politik politische Zeitfenster. Zur Fruchtbarkeit und Anwendbarkeit von Kindons "policy window"-Konzept. Diskussionspapier des IÖW, 54(02).

OECD. (2020). OECD Policy Responses to Coronavirus (COVID-19): Government support and the COVID-19 pandemic. Retrieved from <http://www.oecd.org/coronavirus/ policy-responses/government-support-and-the-covid-19-pandemic-cb8ca170/>. 
OECD. (2020). The COVID-19 crisis in Serbia. Retrieved from <https://www.wb6cif.eu/wp-content/uploads/2020/05/Covid-19-response-in-SRB-27.4.pdf>.

Order on banning gatherings in the Republic of Serbia in public places and indoors, "Official Gazette of RS”, No. 39 of March 21, 2020. Retrieved from <https:/www.paragraf.rs/ glasila/rs/sluzbeni-glasnik-republike-srbije-39-2020.html>.

Rich, A. (2005). Think tanks, public policy, and the politics of expertise. Cambridge University Press.

Rich, A., McGann, J., Weaver, K., Garnett, M., Thunert, M., Speth, R., \& Traub-Merz, R. (2011). Think Tanks in Policy Making-Do They Matter?. Friedrich Ebert Stiftung.

Stone, D. (1996). Capturing the political imagination: Think tanks and the policy process. Psychology Press.

The Government of the Republic of Serbia. (2020). Program of economic measures to mitigate the negative effects of the COVID-19 pandemic and support the Serbian economy. Retrieved from <https://www.mfin.gov.rs/aktivnosti/program-ekonomskih-mera-uputstvo-za-primenu-uredbe-o-fiskalnim-pogodnostima-i-direktnim-davanjima-privrednim-subjektima-u-privatnom-sektoru/>.

United Nations. (2020). World Economic Situation and Prospects: April 2020 Briefing, No. 136. Retrieved from <https://www.un.org/development/desa/dpad/publication/world-economic-situation-and-prospects-april-2020-briefing-no-136/>.

Yin, R. K. (2003). Applied social research methods series. Case study research: Design and methods, 5(1).

Weidenbaum, M. (2010). Measuring the influence of think tanks. Society, 47(2), 134-137.

Wu, T. (2018). Think Tanks' Influence on the Front-End of the Policymaking Process: Empirical Evidence from the United States. American Journal of Management Science and Engineering, 3(4), 30-37.

Zahariadis, N. (1992). To sell or not to sell? Telecommunications policy in Britain and France. Journal of Public Policy, 12(4), 355-376.

Zahariadis, N. (1995). Markets, states, and public policy: Privatization in Britain and France. University of Michigan Press. 


\section{Sobre o autor}

IRENA DJORDJEVIC é membro da Unidade de investigação em Governança, Competitividade e Políticas Publicas (GOVCOPP) na Universidade de Aveiro e coordenadora de pesquisa em Think Tanks híbridos na Sérvia - NALED. O seu background educacional é em jornalismo (Licenciatura) e terrorismo e crime organizado (Mestrado), atualmente está a frequentar o Doutoramento em Ciência Política na Universidade de Aveiro. Como candidata doutoranda, visa transferir a sua experiência prática de política com o mundo da teoria, focando o seu interesse académico no papel dos think tanks e na influência que exercem dentro de diferentes contextos. Nos seus 5 anos de experiência em trabalho político já contribuiu com a introdução de novas soluções políticas na Sérvia como a isenção de impostos para start-ups e a simplificação do compromisso laboral para trabalhadores sazonais.

[https://orcid.org/0000-0001-7182-0178]

\section{About the author}

IRENA DJORDJEVIC is the member of the Research Unit in Governance, Competitiveness and Public Policies (GOVCOPP) at the University of Aveiro and the research coordinator in the hybrid think tank from Serbia - NALED. Her educational background is in journalism (BA) and in terrorism and organized crime (MA), and she is currently doing her PhD in Political Science at the University of Aveiro. As PhD Candidate, aims to transfer her practical policy experience to the world of theory, and focuses her academic interest in the role of think tanks and influence they exercise within different contexts. In her 5-years' policy work experience she has already contributed to the introduction of new policy solutions in Serbia such as tax exemption for start-ups and simplified work engagement for seasonal workers.

[https://orcid.org/0000-0001-7182-0178] 


\section{Appendix}

A. Policy products of selected think tanks published in the period March $15^{\text {th }}$ - May $15^{\text {th }} 2020$

\begin{tabular}{|c|c|c|c|}
\hline \multicolumn{4}{|c|}{ European Policy Center - CEP } \\
\hline No & Date & Title & Category \\
\hline 1 & 23-Mar & $\begin{array}{l}\text { "Houston, we have a problem..." How to prevent the collapse of the Serbian } \\
\text { economy due to the global crisis caused by the corona virus pandemic }\end{array}$ & Blog \\
\hline 2 & 25-Mar & $\begin{array}{l}\text { How to prevent the collapse of the Serbian economy due to the global crisis } \\
\text { caused by the coronavirus pandemic }\end{array}$ & Podcast \\
\hline 3 & 26-Mar & State of emergency and social networks: your right to spread everything? & Blog \\
\hline 4 & 1-Apr & Government measures are good, success depends on implementation & News \\
\hline 5 & 9-Apr & Convention on Economic Measures to Assist the Economy & News \\
\hline 6 & 10-Apr & \#ThinkThankReact: World Solidarity Campaign & News \\
\hline 7 & 13-Apr & Taming the elephant & Blog \\
\hline 8 & $18-A p r$ & Keeping a physical distance, yet keeping the region close & Podcast \\
\hline 9 & 19-Apr & How not to spoil good measures? & Blog \\
\hline 10 & 23-Apr & A look at the future of EU enlargement & News \\
\hline 11 & 24-Apr & $\begin{array}{l}\text { EU, Western Balkans and COVID-19: Preventing EU's cold from causing a } \\
\text { bad fever in the region }\end{array}$ & Podcast \\
\hline 12 & $28-\mathrm{Apr}$ & China-Serbian relations - what we have learned from the COVID-19 crisis & $\begin{array}{l}\text { Policy } \\
\text { Brief }\end{array}$ \\
\hline 13 & 29-Apr & Lack of transparency: COVID-19 pandemic in Serbia & Blog \\
\hline 14 & 4-May & $\begin{array}{l}\text { Work from home during the pandemic: } \\
\text { An opportunity to modernize the work conditions of civil servants }\end{array}$ & $\mathrm{Blog}$ \\
\hline 15 & 13-May & Systemic undermining of EU credibility in the time of Corona & Blog \\
\hline 16 & 15-May & $\begin{array}{l}\text { Greece's Fight Against the Coronavirus: Prosocial Behavior with Genuine } \\
\text { Motives }\end{array}$ & Blog \\
\hline \multicolumn{4}{|c|}{ European Movement in Serbia-EMINS } \\
\hline No & Date & Title & Category \\
\hline 1 & Apr & Parliament and Corona & Info-graph \\
\hline 2 & 10-Apr & EUROPEAN NEWS: Economic recovery plans & News \\
\hline 3 & 13-Apr & $\begin{array}{l}\text { Civil society in the region for a regional approach to the fight against } \\
\text { COVID-19 }\end{array}$ & News \\
\hline 4 & 22-Apr & Serbia after Coronavirus: Foreign Trade, Vladimir Medjak & Video \\
\hline 5 & 24-Apr & EUROPEAN NEWS: Travels during COVID-19 & News \\
\hline 6 & 28-Apr & $\begin{array}{l}\text { Serbia after Coronavirus: Consequences for the labor market, Jelena } \\
\text { Žarković }\end{array}$ & Video \\
\hline
\end{tabular}




\begin{tabular}{|c|c|c|c|}
\hline 7 & 29-Apr & $\begin{array}{l}\text { Joint Statement by the Western Balkans Civil Society on COVID-19 } \\
\text { Pandemic }\end{array}$ & $\begin{array}{l}\text { Media } \\
\text { Statement }\end{array}$ \\
\hline 9 & 5-May & $\begin{array}{l}\text { Serbia after Coronavirus: Ahead of the EU-Western Balkans Summit, Jelica } \\
\text { Minić }\end{array}$ & Video \\
\hline 10 & 14-May & Serbia after Coronavirus: Youth in the labor market, Đorđo Cvijović & Video \\
\hline \multicolumn{4}{|c|}{ National Alliance for Local Economic Development-NALED } \\
\hline No & Date & Title & Category \\
\hline 1 & 16-Mar & $\begin{array}{l}10 \text { measures for supporting businesses and jobs during and after the Corona } \\
\text { virus crisis }\end{array}$ & $\begin{array}{l}\text { Media } \\
\text { Statement }\end{array}$ \\
\hline 2 & 17-Mar & COVID-19: Join the dialogue & Platform \\
\hline 3 & 18-Mar & $\begin{array}{l}\text { NALED Mapped Out the Cities and Municipalities Where Assistance to } \\
\text { Older People is Top Priority }\end{array}$ & $\begin{array}{l}\text { Policy } \\
\text { brief }\end{array}$ \\
\hline 4 & 19-Mar & $\begin{array}{l}\text { NALED Proposes } 15 \text { Urgent Measures for the Healthcare System During } \\
\text { the COVID-19 }\end{array}$ & Info-graph \\
\hline 5 & 19-Mar & $\begin{array}{l}\text { NALED Proposes } 15 \text { Urgent Measures for the Healthcare System During } \\
\text { the COVID-19 }\end{array}$ & Info sheet \\
\hline 6 & 26-Mar & $\begin{array}{l}\text { The Contact Center for Reporting Irregularities During the COVID-19 } \\
\text { Pandemic Opened }\end{array}$ & $\begin{array}{l}\text { Media } \\
\text { Statement }\end{array}$ \\
\hline 7 & 30-Mar & $\begin{array}{l}\text { Brief questionnaire on the effects of COVID-19 on businesses and local } \\
\text { communities }\end{array}$ & $\begin{array}{l}\text { Policy } \\
\text { analysis }\end{array}$ \\
\hline 8 & 31-Mar & $\begin{array}{l}\text { Brief questionnaire on the effects of COVID-19 on businesses and local } \\
\text { communities }\end{array}$ & Info-graph \\
\hline 9 & 31-Mar & What do businesses expect from the announced support measures & $\begin{array}{l}\text { Media } \\
\text { Statement }\end{array}$ \\
\hline 10 & 31-Mar & $\begin{array}{l}\text { The State's Program of Economic Measures for Supporting Businesses } \\
\text { During the COVID-19 Pandemic Presented }\end{array}$ & News \\
\hline 11 & 1-Apr & Support measures are an important "time out" for the economy & $\begin{array}{l}\text { Media } \\
\text { Statement }\end{array}$ \\
\hline 12 & 3-Apr & NALED Launched a Platform for Donations to Cities and Municipalities & $\begin{array}{l}\text { Media } \\
\text { Statement }\end{array}$ \\
\hline 13 & 3-Apr & NALED Launched a Platform for Donations to Cities and Municipalities & Platform \\
\hline 14 & 7-Apr & $\begin{array}{l}\text { Business Associations' Recommendations for Implementing Economic } \\
\text { Measures }\end{array}$ & $\begin{array}{l}\text { Media } \\
\text { Statement }\end{array}$ \\
\hline 15 & 10-Apr & Five Emergency Measures to Assist Farmers and Beekeepers & Info-graph \\
\hline 16 & 10-Apr & $\begin{array}{l}\text { Regulations on Implementing Economic Measures to Assist Businesses } \\
\text { Adopted }\end{array}$ & News \\
\hline 17 & 10-Apr & Five Emergency Measures to Assist Farmers and Beekeepers & $\begin{array}{l}\text { Policy } \\
\text { brief }\end{array}$ \\
\hline 18 & 10-Apr & COVID-19: Problems and solutions & Platform \\
\hline 19 & 13-Apr & $\begin{array}{l}\text { NALED Proposes } 20 \text { Measures to Support the Construction Industry and } \\
\text { Infrastructure and Transport Sectors }\end{array}$ & Info sheet \\
\hline 20 & 23-Apr & Abolish VAT on donations involving food and hygiene products & $\begin{array}{l}\text { Media } \\
\text { Statement }\end{array}$ \\
\hline
\end{tabular}




\begin{tabular}{|c|c|c|c|}
\hline 21 & 4-May & Together we make a difference in battling COVID-19 & News \\
\hline 22 & 7-May & $\begin{array}{l}\text { Businesses donated } 45 \text { tons of food to } 10,000 \text { households in cooperation } \\
\text { with NALED }\end{array}$ & $\begin{array}{l}\text { Media } \\
\text { Statement }\end{array}$ \\
\hline \multicolumn{4}{|c|}{ National Coalition for Decentralization - NCD } \\
\hline No & Date & Title & Category \\
\hline 1 & 27-Mar & $\begin{array}{l}\text { APPEAL to RTS and crisis headquarters: Educate citizens on necessary } \\
\text { protective measures during the Coronavirus epidemic }\end{array}$ & $\begin{array}{l}\text { Media } \\
\text { statement }\end{array}$ \\
\hline 2 & 2-Apr & By centralizing information to even more misinformation at the local level & $\begin{array}{l}\text { Media } \\
\text { statement }\end{array}$ \\
\hline 3 & 8-May & Pandemic and Economy: The Reality Behind the Numbers & $\begin{array}{l}\text { Online } \\
\text { Debate }\end{array}$ \\
\hline 4 & 4-May & Hand washing, brainwashing and rating of measures "against" the Corona & $\begin{array}{l}\text { Online } \\
\text { Debate }\end{array}$ \\
\hline 5 & 7-May & $\begin{array}{l}\text { Research results: Availability of information on the local level at the time of } \\
\text { the corona }\end{array}$ & $\begin{array}{l}\text { Survey } \\
\text { results }\end{array}$ \\
\hline 6 & 15-May & $\begin{array}{l}\text { Expensive borrowing by Serbia in order to preserve the illusion of economic } \\
\text { growth }\end{array}$ & $\begin{array}{l}\text { Online } \\
\text { Debate }\end{array}$ \\
\hline
\end{tabular}

